\title{
The Initial Exploration to Leisure Education for Business English Majors
}

\author{
Zhang Yuhuan ${ }^{1, a^{*}}$ \\ ${ }^{1}$ School of Foreign Languages, China West Normal University, China No. 1 Shi Da Road, Shunqing \\ District, Nanchong, 637009, Sichuan, China \\ ajuliezhyh@163.com
}

Keywords: Leisure education; Business English majors; Reality; Implication

\begin{abstract}
With the reform and development of colleges and universities, they put the flexible credit system into practice, showing college students have more leisure time than before. Students' confusion and idleness happen with their leisure time increasing. They have taken entering an ideal university as their ultimate goal. As they have a chance to study at colleges, they have no goal or need to support their college studies. Moreover, business English has its own business templates and economic policies are changing with time, so it seems that business English majors are unnecessary to spend much time on business knowledge, but business English emphasizes practice and business English teachers have to put more attention to business English majors' leisure time. Teachers put more emphasis on life-long and self-development leisure education which can give off greater powers helpful for students' future life.
\end{abstract}

\section{Introduction}

With the rapid growth of productivity, China has entered a new century, in which people have been liberated from labors; as people's living standards improve, people have increasing leisure time to attach importance to the things which they are interested in. For the college students entering the ivory towers, they have stayed away from entrance examinations pressures in senior high school. Compared with students in senior high school, they have a lot of leisure time; in senior high school, students have to arrange their learning and reviewing plans according to teachers' paces and plans. Suddenly entering a completely new environment, where learning methods and learning states are quite different from that in senior high school, students in ivory towers feel so disoriented and bewildered. Facing so much leisure time, they are chasing feeling of freshness and indulging themselves. In addition, with reform of college education fully under way, a vast number of universities and colleges have carried out flexible schedules and credit system; as a result, students have increasing leisure time for them to be free to plan and arrange. Furthermore, teaching methods differ from traditional education in senior schools; students at colleges have more leisure time to look for information, attend class discussions and get their ideas heard. That calls for reasonable and efficient use of leisure time. The popularization of science and technology has made great contribution to economy and education. Science and technology is have influenced people's lives in an unprecedented breadth and depth, changing peoples' views and understanding of education and subverting people's values; meanwhile, they have given people more freedom and leisure time. Without doubt, informatization provides possibility of processing business transactions for business English majors across time and space; informatization also provides convenience to business English majors with a huge number of business soft-wares and solution templates. Therefore, informatization, to some degree, has rescued business English majors from tedious learning. Students spend no more time on rote memory of business correspondence and business tables; thus, students have more time in business English. As a matter of fact, leisure time dominates in students' university life. How to make good use of leisure time is an inevitable question. The quality and quantity of leisure time plays an important role in all-round and harmonious development of college students. For business English majors, how to take advantage of leisure time in their college life is good to their personal business ability and personal charm. 


\section{Related Definition and Researches}

Leisure education has become an urgent problem to solve in educational circles; it is necessary to know about the connotations of leisure and leisure education. Leisure, simply speaking, means free time, rest time or self-controlled time, which is self-dominated time according individual will. People live in time, but most of the time belong to word, health and study, etc, which people cannot arrange according to personal arbitrariness. In different stages of time, people take corresponding measures to approach and achieve their goals according to their established aims, so people belong to goals and plans in the most of time. However, leisure is part of people's life. People can rationally settle their leisure time according to their inner experience and needs, so leisure plays a significant role in raising personal sentiment and creating chances of developing potentials, and it has inestimable influence on students' socialization and maturity as a method of touching society and knowing about other people.[1] Experts in China mainly have three different opinions: one opinion regards leisure education as education in people's spare time; Another think that leisure education is an education to teach people how to make use of leisure time and how to improve the quality of leisure time; one more opinion thinks that leisure education is an educational activity to improve and enrich people's mental states.[2] College students' leisure education is defined as an education which guides college students to set up the correct value of leisure time, form and master knowledge, habits, abilities and skills of utilizing leisure time valuably and cultivate their interests, talents and aptitudes according to their potentials in orders to promote the all-around development of their own qualities and improve their life standards.[3] However, this thesis focus on business English majors. The purpose is to help business English majors establish correct leisure value-how to take advantage of leisure time to enrich their extracurricular Life, business professional knowledge, skills and etiquette.

Researches on leisure education in foreign countries can date back to the British philosopher and educator named Spencer. He has predicted that people would have more leisure time with productivity improvement which has improved mode of production and saved labors, so leisure education has becoming more and more important. [4] Compared with leisure education in China, related research first appeared in 1983. At that time, although researches on leisure education was not combined with Chinese reality, it opened the prelude to leisure education in our country. Until 1980s, the number of researches on leisure education was less than ten every year. In 21 st century, more and more educational experts have begun to focus on leisure time education. Since 2005, the number of leisure education was above 100. Unluckily, even nowadays, the theme of leisure education on foreign language is very few, among which is no paper about leisure education on business English on CNKI website. Along with China entering WTO and foreign trade system deepening, increasing foreign companies come into China for market-seeking; Chinese companies have gotten more chances to move towards world. More and more frequent exchanges and communication between enterprises need business English professional talents. Business English is a new majors for most of people, but many colleges have settled business English as a major. It is proved that business English has been welcome. In order to make use of college life to develop their comprehensive quality, higher requests of leisure arrangement and utilization is put forward.

\section{The Reality of Leisure Education for Business English Majors}

For numerous college students, compared with the previously busy stage of senior high school and the latter competitive stage of work, college is a relatively relaxed and leisure stage. During tense and busy study stage in high school, teachers always encourage and stimulate students to study every minute to its full value with such words-now work hard and if you enter the university, you'll have much leisure to play your games. Most of them kill their wills and waste their spare time on the internet. Moreover, business English, for them, is a completely new major, coming to a strange environment with much spare time and an uncertain future. What's worse, their leisure time has been passive to be put in enslaved status; therefore, when they really have a lot of free time available, they do not know how to manage it. What's most important, extremely complex written program of foreign trade about preparing 
documents and filling in documents, etc before has its own unity of the template on the websites, so there is no need for business English majors to spend overtime reciting related tables. In most cases, business English can use office integration software or business software to solve the problems, only to find that it can make the college students save a lot of time and spirits, which can cause to feint phenomenon-related business knowledge has its own fixed templates, so business English majors are unnecessary to learn business-relating knowledge. But the reality is this major requires higher practical ability, which suggests higher requirement for the business English teachers: they not only are well acquainted with business knowledge, but also are familiar with the requirements of business English professional talents that enterprises need and understand the students' psychology, with the purpose of making a batch of qualified business English talents to meet markets' needs on the basis of training objectives of business English.

As is known to all, college students' learning time, except summer and winter vocations, is about 280 days. Removing about 100 days of weekends and holidays again, it shows that college students' leisure time account for almost half of the year. In addition, many college and universities at present carry out the flexible credit system, meaning college students have increasing leisure time. Once the addition to an ideal university as the ultimate goal in high school, their leisure time since primary school has been occupied with many kinds of interest-oriented classes and training classes; Intense and brutal competition mechanism under the control of the college entrance examination education excessively emphasizes scores, neglecting education's own function of individual's socialization and personalization and properties of its characteristics. Experiencing the solemn and stirring scene of college entrance examination like a large number of mounted and foot soldiers passing single-plank bridge, once they achieve the ultimate goal of entering universities, they lose their value need. With no aim and no need to support the college students, part of them take up with depression, inertness, idleness and puzzlement, resulting in their blind, spontaneous and unwaking states of leisure life.[5] combining with the reality of business English majors at the writer's university, the writer, by way of observing and communicating with students and teachers, knows about that the college organizes business English majors to take part in a large civic party with a strong taste of business (mainly sophomores take part in the party ) every year; every year one to two team participate in a variety of industry or enterprise business skills competition(mainly junior or senior participate in the competition, each team with three members); all the sophomores have a chance as a corporate trainee. Except the special time of business English professional activities, they still have much leisure time. Most business English majors chat on line, play games, see films, watch series; a few students have their part-time job in their spare time. A very few students spend time on English study and business study.

\section{Implication in Business English Teaching}

China is still at the primary stage of socialism, still a developing country faced with various challenges. This is our basic national conditions, which is a true China. Therefore, leisure education cannot be achieved overnight, but with the improvement of working conditions and life standards, it can be predicted that leisure education will be attracting people's more attention. Business English teachers, whom are named as the engineers of human soul, are burdened with the responsibilities of educating or molding their students. It is more important they should now the value orientation of modern leisure education.

For the object of business English majors, they should be beneficiaries of leisure education because leisure time has dominated their college life. On the one hand, the business English teachers focuses on life-long leisure education. Particularly, the objects have been passive to attend educational activity because they have to follow the teachers' plans and teaching paces in their most of study life since their kindergarten. Before the teachers let students manipulate and manage their own leisure time, it is necessary for teachers to train students' various abilities of active application of leisure time and cultivate their autonomous consciousness on how to control their leisure time independently. Teachers after classes, guide students to spend their leisure time on English study and business exercises. Moreover, teachers let students understand that economic policies change with time, so it is necessary for business 
English students to refresh their knowledge store whenever and wherever possible, so making use of their leisure time to know about business policies and rules is the presupposition as a successful business man in the international trades. It is acknowledged that there are internal and close relations between necessary social labor time and the structure of higher education. Without doubt, social productivity has gone fast and effectively risen since machines instead of backward manual labors while the internet has helped boost the productivity all over the world, including China in the informational times. That means people may have more leisure time after their work, so leisure education fall into life-long education which is worth of consideration early. On the other hand, teachers should know that students' potentials, powers and creativeness are infinite and their talents can be fully released and developed in their autonomous and voluntary states, so business English teachers focus on their students' self-development leisure education. That is to say, business English teachers do not train their students as slaves of jobs in the future, but intend to help students to find their English and business sustainable abilities in their teaching. How to help business English students manage their leisure time, find their own talents in learning English and get skill in dealing with various emergencies during the stages of business affairs is obviously significant for business English teachers in their teaching life. Leisure education will not be a burden but continuation and development of normal education and can bring out a new situation in which education flourishes as never before.

\section{Conclusion}

With productivity improved and working time reduced, people have more leisure time; With the university reform and development in education, most of colleges and universities have begun to carry out the credit system, meaning students have more leisure time. At the same time, students make different choices of leisure time, such as sleeping, chatting on the line, napping, playing computer games and killing the time with nothing, etc. For business English majors, business English is a completely new and strange specialty. To be successful a worker in their future international trade, they have to spend more time on English study and business knowledge accumulation than others, so it is necessary for them to make good use of leisure time in their college life in order to waste their spare time; meanwhile, students can prepare for their future jobs ahead of time. Business English teachers not only help business English majors get various abilities of using leisure time actively and cultivate the students' autonomous consciousness of controlling their leisure time but also guide students to develop their leisure education, which will benefit their getting sustainable ability of learning English and dealing with business affairs in the future internal trade. Leisure education is to teach students how to spend their leisure time significantly and efficiently.

\section{References}

[1] Liu Xiangping. (2001). Psychological Problems and Leisure Education of Contemporary Students. Teacher Education Research. Vol.13, No.4.

[2] Pang Guimei. (2004). Theory of Leisure Education. Nanjing: Jiangsu Education Press. P 61.

[3] Cao Yuxia. (2006). The Initial Exploration to College Students' Leisure Education in the New Period. Master's Degree Thesis of Shandong Normal University

[4] Chen Guisheng. (2000). Principles of Education. Shanghai: East China Normal University Press. P153-155.

[5] Zhu Zhengping. (2005). On Leisure Life and Leisure Education of Contemporary College Students. Master's Degree Thesis of Hunan Normal University. P18. 